\title{
DESAIN KURIKULUM PENDIDIKAN ISLAM BERBASIS TAUHID
}

\author{
Tri Wahyudi Ramdhan, M.Pd.I \\ Dosen PAI STAI Darul Hikmah Bangkalan \\ wahyudi@darul-hikmah.com
}

\begin{abstract}
Abstrak
Kajian ini merupakan Library Research atau penelitian pustaka yang ditulis berdasarkan hasil kajian terhadap berbagai bahan pustaka yang relevan, baik berupa buku, jurnal, artikel dan lain sebagainya yang terkait dengan fokus masalah di atas. Data-data yang terkumpul dalam penelitian ini selanjutnya dianalisis dengan menggunakan analisis isi (content analysis). Hasil dari tulisan ini adalah pembelajaran tauhid dan akhlak harus diprioritaskan dengan arti peserta didik harus dikenalkan dengan ketauhidan terlebih dahulu sebelum materi ibadah dan keterampilan dan juga muatan tauhid harus mewarnai materi-materi pelajaran lain dalam setiap Kompetensi Dasar atau Indikator Pencapaiannya
\end{abstract}

Kata Kunci: Desain, Kurikulum Pendidikan Islam

\section{A. Pendahuluan}

Banyak teori tentang kurikulum yang telah ditulis oleh pakar pendidikan, baik dari kalangan pakar pendidikan barat atau Islam. Secara umum, kurikulum meliputi empat unsur utama, yaitu tujuan yang hedak dicapai, materi atau konten yang harus diberikan kepada peserta didik, metode dan media yang dipakai dalam penyampaian materi untuk mencapai tujuan yang diinginkan, dan evaluasi yang dilakukan untuk mengukur ketercapaian tujuan. Kurikulum dengan jabaran di atas adalah pengertian kurikulum secara luas, sedangkan kurikulum dalam arti sempit hanyalah memuat konten atau materi.

Mengingat begitu luasnya cakupan kurikulum, maka penulis dalam makalah ini hanya membatasi diri pada kurikulum dalam arti sempit saja dengan fokus utamanya adalah Desain Kurikulum Pendidikan Islam dengan Pendekatan Historis dan Pendekatan Religius.

\section{B. Kurikulum Pendidikan Islam}


Sebelum lebih jauh berbicara tentang desain kurikulum pendidikan Islam, penulis menganggap penting menjelaskan tentang materi atau konten yang harus diajarkan kepada peserta didik. Materi atau konten yang harus diketahui oleh peserta didik melalui pendidikan disebut dengan ilmu ( $\mathrm{al}$ - ' $\mathrm{ilm}$ ). Ilmu dimaksud adalah segala yang terkadung di dalam Alqur'an sebagai kitab induk umat Islam dan implementasinya yang tercermin dalam ucapan, tindakan, dan ketetapan yang muncul dari baginda Rasulullah, Muhammad Shallallahu 'Alaihi Wasallam. Dengan pendek kata, konten atau materi pendidikan Islam adalah Kalam Ilahi dan Sabda Nabi.

Muhammad Syadid, saat membahas tentang Ilmu dalam bukunya, menyebutkan bahwa yang dimaksud dengan ilmu di dalam Alqur'an adalah segala macam pengetahuan apakah itu bersinggungan dengan ritual, sosial, dan lain-lain, sebab di dalam Alqur'an sendiri tidak hanya berisi tentang

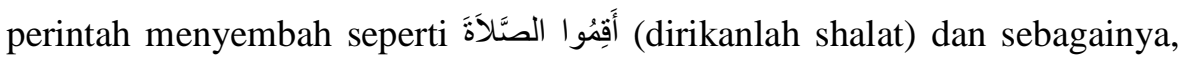
melainkan juga ada perintah mengasah otak untuk menemukan kebesaran Tuhan misalnya firman Allah dalam surat al-Rum ayat $20-25$. Salah satu ayat tersebut adalah,

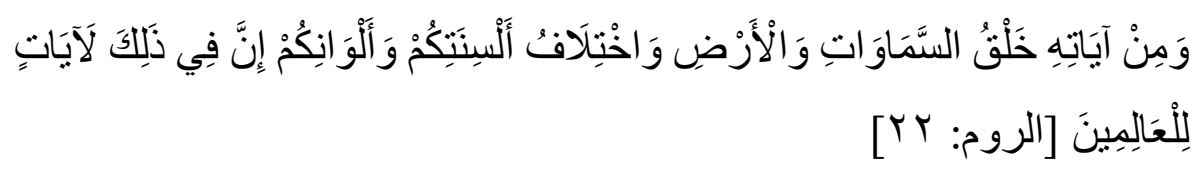

"dan di antara tanda-tanda kekuasaan-Nya ialah penciptaaan langit dan bumi dan berlain-lainan bahasamu dan warna kulitmu. Sesungguhnya pada yang demikan itu benar-benar terdapat tanda-tanda (kebesaran-Nya) bagi orang-orang yang mengetahui (berilmu)."

Di dalam surat dan ayat yang lain difirmankan,

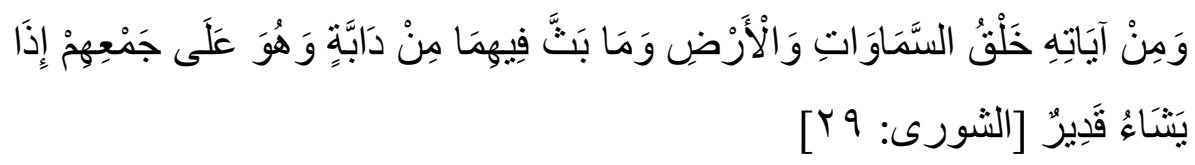

"di antara (ayat-ayat) tanda-tanda-Nya ialah penciptaan langit dan bumi dan makhluk-makhluk yang melata yang Dia sebarkan pada keduanya. dan Dia Maha Kuasa mengumpulkan semuanya apabila dikehendaki-Nya.' 
Maha besar Allah bagi bagi orang-orang yang dibukakan pintu tanda kebesaran-Nya baginya. Pada surat al-Rum disebutkan tanda-tanda kebesaran atau kekuasaan Allah terdapat pada penciptaan langit dan bumi, pada surat alSyura disebutkan tidak hanya pada langit dan bumi simpul kebesaran Allah tetapi juga terdapat pada binatang-binatang melata yang ada di muka bumi. Allah berfirman,

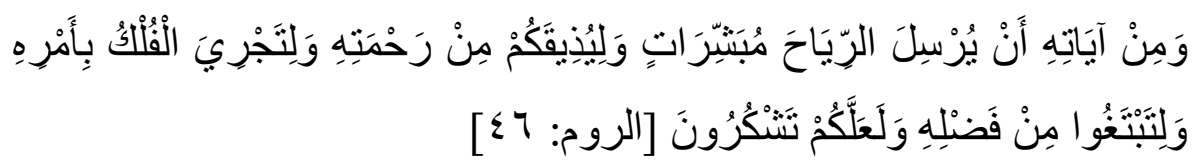

"dan di antara tanda-tanda kekuasan-Nya adalah bahwa Dia mengirimkan angin sebagai pembawa berita gembira dan untuk merasakan kepadamu sebagian dari rahmat-Nya dan supaya kapal dapat berlayar dengan perintahNya dan (juga) supaya kamu dapat mencari karunia-Nya; mudah-mudahan kamu bersyukur."

Angin dan udara yang senantiasa mengisi ruang antara langit dan bumi merupakan tanda kebesaran Allah. Dari agin ini ada manfaat yang dinikmati seluruh manusia yaitu ia membawa kabar gembira bagi umat manusia dengan perubahan arah angin yang semula bertiup dari arah timur ke barat lalu berubah dari barat ke timur itu merupakan pertanda akan adanya hujan yang ditunggu-tunggu manusia. Selanjutnya hujan tersebut akan menumbuhkan dan menyebabkan terjadinya pembuahan banyak tanaman yang dibutuhkan oleh manusia sehingga manusia mampu menikmati tanaman tersebut sebagai bentuk rahmat yang turun dari Allah. Manfaat lain dari bertiupnya angin itu adalah perahu layar dapat berjalan di lautan ${ }^{1}$ sehingga manusia pun dapat mencari karunia Allah yang berada di samudera atau pun sebagai sarana lalu lintas laut. Hal ini berkat rahmat Allah yang berwujud angin. Bak gayung bersambut antara ayat di atas dengan ayat berikut ini,

\footnotetext{
${ }^{1}$ Abu Manshur Muhammad bin Muhammad al-Maturidi, Tafsir al-Maturidi, Dar alKutub al-'Ilmiyyah, Beirut Lubnan, cet. 1, 2005, Juz 8, h. 287.
} 


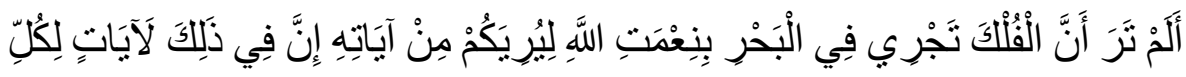
صَبَّارِ شَكُورِ [لقمان: آنَ]

"tidakkah kamu memperhatikan bahwa sesungguhnya kapal itu berlayar di laut dengan nikmat Allah, supaya diperlihatkan-Nya kepadamu sebahagian dari tanda-tanda (kekuasaan)-Nya. Sesungguhnya pada yang demikian itu benar-benar terdapat tanda-tanda bagi seтиa orang yang sangat sabar lagi banyak bersyukur."

Dalam surat Lukman ini, Allah justru menantang manusia untuk memikirkan, merenungkan, dan meneliti (nazhar) dengan tekun dan sabar tentang kapal yang berlayar di permukaan laut sehingga dari pemikiran, perenungan, dan penelitin tersebut membuahkan hasil tentang kebebsaran dan ke-Mahakuasa-an Allah. ${ }^{2}$ Perintah perenungan tentang ciptaan Allah yang ada di muka bumi juga terlihat dalam surat al-Ghasyiyah ayat $17-20$ berikut ini,

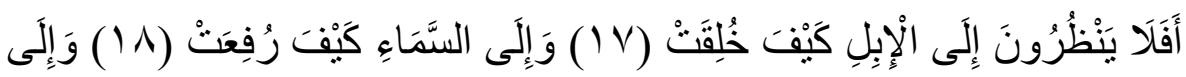

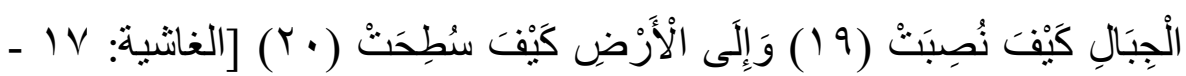

"Maka Apakah mereka tidak memperhatikan unta bagaimana Dia diciptakan, dan langit, bagaimana ia ditinggikan? dan gunung-gunung bagaimana ia ditegakkan? dan bumi bagaimana ia dihamparkan?"

Semakin disibak ayat-ayat Alqur'an tentang obyek perenungan dan penelitian, kian terkuak banyak aspek yang harus kita renungkan dan pelajari. Beberapa ayat di atas menandakan bahwa ilmu yang harus dipelajari dan harus dirancang dalam kurikulum itu bersifat umum, tidak hanya ilmu pada aspek ritual saja. Dorongan Allah untuk merenungkan dan mempelajari unta, langit, gunung, bumi, angin, perahu, dan lautan, itu tidak semata-mata dorongan melihat dengan kedua mata kita, melainkan dorongan untuk melihat

${ }^{2}$ Abu Muhammad Abdu al-Haqq bin 'Athiyyah, al-Muharrar al-Wajiz fi Tafsir alKitab al- 'Aziz, Dar al-Kutub al-'Ilmiyyah, Beirut, cet. 1, 1422 H., Juz 4, h. 335. 
dengan pikiran mendalam (nazhar) hingga sampai pada simpulan bahwa di balik semua itu adalah Allah Yang Maha Kuasa. ${ }^{3}$

Hal ini dapat dilakukan dengan pola lama seperti pengendara menunggang unta menghindari keramaian manusia sembari menghayati apa yang dialaminya dengan memikirkan betapa besarnya kuasa Allah dengan memberikan kekuatan lebih untuk unta daripada binatang lainnya, kemudian pengendara mendongak ke langit dan sesekali menundukkan kepala ke arah bumi dengan mengingat Pencipta Sejati. Al-Qurthubi menegaskan bahwa yang demikian ini dapat mengantarkan seseorang menemukan Sang Pencita unta, langit, dan bumi. ${ }^{4}$

Selain pola lama seperti di atas, menalar penciptaan tiga makhluk Allah di atas dapat pula dilakukan dengan pola baru yaitu menjadikan tiga ciptaan tersebut sebagai insiprasi lahirnya ilmu pengetahuan, yang dalam istilah Abbas Mahjub disebut dengan "ziyadah al-tsaqafah wa al-ma'rifah", misalnya lahirnya ilmu biologi dari proses memikirkan unta, ilmu astronomi dengan merenungkan pencitaan langit, angin, dan ilmu-ilmu lain.

Penyebutan beberapa obyek pengetahuan yang menjadi tanda kebesaran Allah sebagaimana disebutkan di atas itu merupakan sampel saja yang dihadirkan Allah di hadapan kita. Intinya, segala macam yang ada di bumi, di langit, dan di antara keduanya adalah obyek pengetahuan yang harus dipelajari. Dengan demikian konten atau materi yang harus diberikan kepada peserta didik sifatnya adalah umum, tidak tertentu pada satu aspek ilmu saja.

${ }^{3}$ Abbas Mahjub, al-Tarbiyyah Fi 'Ushuri ma Qabla al-Islam wa Ba'dahu, Jami'ah Ummu al-Qura, 1980, h. 112.

${ }^{4}$ Abu 'Abdillah Muhammad bin Ahmad al-Qurthubi, al-Jami' li Ahkam al-Qur'an, Dar al-Kutub al-Mishriyyah, Kairo, cet. 2, 1964, Juz 20, h. 36.

5 Abbas Mahjub, al-Tarbiyyah Fi 'Ushuri ma Qabla al-Islam wa Ba'dahu, Jami'ah Ummu al-Qura, 1980, h. 113. Berikut ini, ungkapan asli dari Abbas Mahjub, فكانت هذه الآيات ومثيلاتها في القرآن بواعث على إعمال العقل و النظر في الكون و التأمل فيه، مما

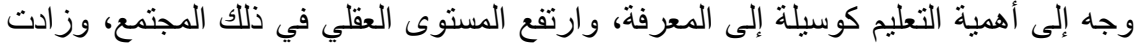
التقافة والمعرفة من القرآن. 
Saat Rasulullah mewanti-wanti agar umatnya mencari ilmu dengan ketetapan bahwa mencari ilmu itu hukumnya wajib bagi setiap muslim, maka yang dimaksud ilmu oleh Rasulullah adalah segala macam ilmu yang disebutkan di dalam Alqur'an dengan segala macam ragam dan cabangcabangnya. Hanya saja, berbagai macam aspek ilmu tersebut harus ditata, dikelola, dan ditentukan skala prioritasnya. Maka dari itu, al-Ghazali datang memberikan rambu-rambu mencari ilmu ada yang bersifat wajib individual (fardlu 'ain) dan ada yang bersifat wajib komunal (fardlu kifayah). ${ }^{6}$

\section{Desain Kurikulum Pendidikan Islam Pendekatan Religius}

Implementasi pendidikan Rasulullah saw. dengan memprioritaskan ajaran tauhid seperti diulas di atas tentu tidak lepas dari bimbingan wahyu. ${ }^{7}$ Dengan kata lain, konteks sejarah tentang prioritas pendidikan tauhid yang dipraktikkan Rasulullah merupakan cerminan kehendak Allah. Sehingga, dapat dikatakan bahwa implementasi pendidikan Rasulullah saw. di atas merupakan firman Allah yang tecipta (ayat kauniyyah). Akan tetapi, untuk memantapkan ayat kauniyyah-Nya ini, Allah menuntun Rasulullah saw. dalam mendesain kurikulum (materi pelajaran) dengan cara menurunkan ayat qur'aniyyah-Nya, yaitu firman-Nya yang menceritakan pendidikan Luqman al-Hakim terhadap putranya, sebagaimana tertuang dalam surat Luqman ayat 13-19,

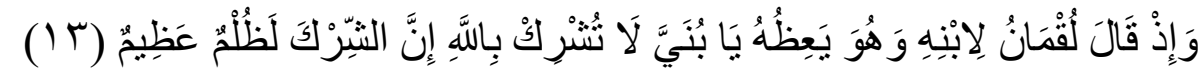

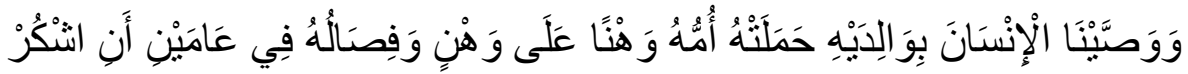

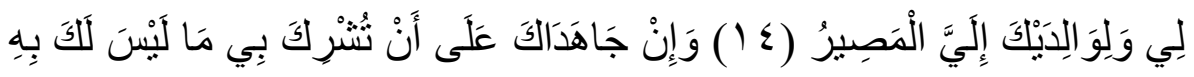

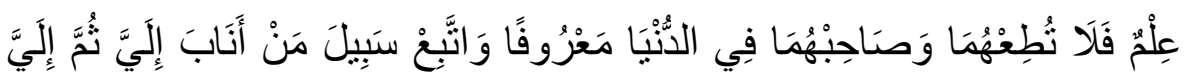

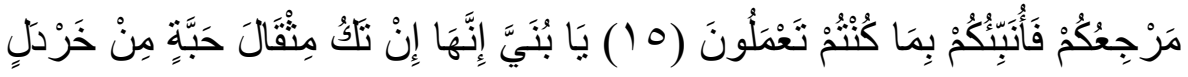

\footnotetext{
${ }^{6}$ Abu Hamid Muhammad bin Muhammad al-Ghazali, Ihya' 'Ulum al-Din, Dar alMa'rifah, Beirut, tt., Juz 1, h. 13.

${ }^{7}$ QS. al-Najm ayat 4.
} 


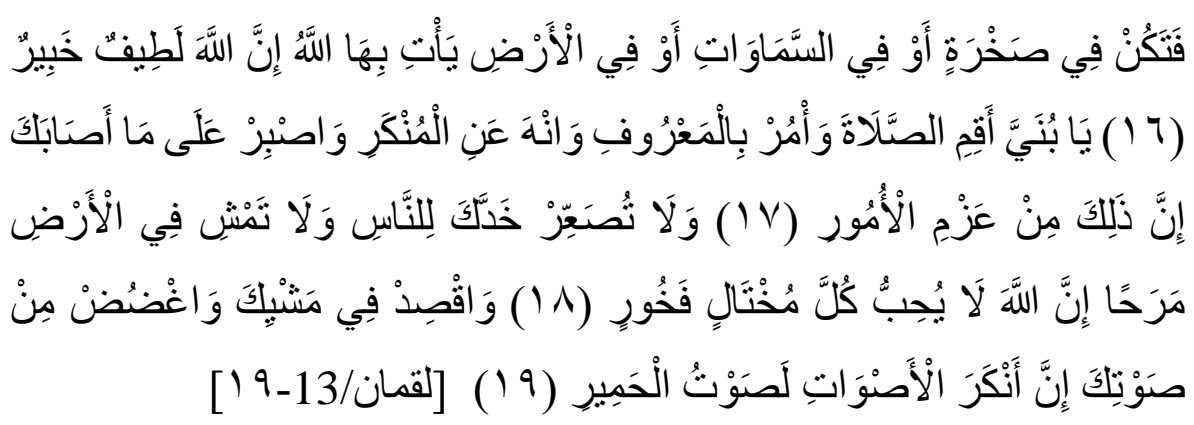

"Dan (ingatlah) ketika Luqman berkata kepada anaknya, di waktu ia memberi pelajaran kepadanya: "Hai anakku, janganlah kamu mempersekutukan Allah, sesungguhnya mempersekutukan (Allah) adalah benar-benar kezaliman yang besar. Dan Kami perintahkan kepada manusia (berbuat baik) kepada dua orang ibu-bapanya; ibunya telah mengandungnya dalam keadaan lemah yang bertambah-tambah, dan menyapihnya dalam dua tahun. Bersyukurlah kepadaKu dan kepada dua orang ibu bapakmu, hanya kepada-Kulah kembalimu. Dan jika keduanya memaksamu untuk mempersekutukan dengan Aku sesuatu yang tidak ada pengetahuanmu tentang itu, maka janganlah kamu mengikuti keduanya, dan pergaulilah keduanya di dunia dengan baik, dan ikutilah jalan orang yang kembali kepada-Ku, kemudian hanya kepada-Kulah kembalimu, maka Kuberitakan kepadamu apa yang telah kamu kerjakan. (Luqman berkata): "Hai anakku, sesungguhnya jika ada (sesuatu perbuatan) seberat biji sawi, dan berada dalam batu atau di langit atau di dalam bumi, niscaya Allah akan mendatangkannya (membalasinya). Sesungguhnya Allah Maha Halus (mengetahuai segala sesuatu sekecil apapun) lagi Maha Mengetahui. Hai anakku, dirikanlah shalat dan suruhlah (manusia) mengerjakan yang baik dan cegahlah (mereka) dari perbuatan yang mungkar dan bersabarlah terhadap apa yang menimpa kamu. Sesungguhnya yang demikian itu termasuk hal-hal yang diwajibkan (oleh Allah). Dan janganlah kamu memalingkan mukamu dari manusia (karena sombong) dan janganlah kamu berjalan di muka bumi dengan angkuh. Sesungguhnya Allah tidak menyukai orang-orang yang sombong lagi membanggakan diri. Dan sederhanalah kamu dalam berjalan dan lunakkanlah suaramu. Sesungguhnya seburukburuk suara ialah suara keledai.” (QS. Luqman: 13-19)

Secara gamblang, ada lima pesan yang hendak disampaikan Allah melalui firman-firman-Nya di atas, yaitu: (1) mengajarkan umat Islam agar mentauhidkan (meng-esa-kan) Allah, (2) mengajarkan akhlak yang baik pada kedua orang tua, terutama ibu, (3) mengajarkan akhlak yang baik kepada 
Allah dengan cara muraqabah (merasa diri selalu diawasi Allah), (4) mengajarkan ibadah, dan (5) mengajarkan akhlak yang baik antar sesama. ${ }^{8}$

Dari lima pesan Allah di atas, ajaran tauhid menempati peringkat pertama. Ini mengindikasikan, bahwa materi pelajaran pertama yang harus diberikan pada anak didik adalah keimanan dan ketauhidan, ${ }^{9}$ sehingga hati anak didik menjadi mantap bertuhan hanya kepada Allah, tidak menyekutukan-Nya dengan sesuatu apapun. Tak kalah penting dari hal itu, segala tindakan dan perbuatan anak didik mampu mencerminkan tindakan dan perbuatan Allah swt. Istilah tasawwufnya adalah, anak didik itu akan melihat sesuatu dengan penglihatan Allah, mengatakan sesuatu dengan ucapan Allah, meraba sesuatu dengan tangan Allah, menuju sesuatu dengan jalan yang dibimbing Allah, dan seterusnya. ${ }^{10}$ Sehingga, mata, mulut, tangan, kaki, dan seluruh anggota tubuhnya akan digunakan pada hal-hal yang tidak dilarang oleh Allah.

Selain firman Allah dalam surat Luqman di atas, hadits Nabi juga memberikan tuntunan praktis tentang desain kurikulum pendidikan Islam. Dalam salah satu haditsnya, beliau bersabda:
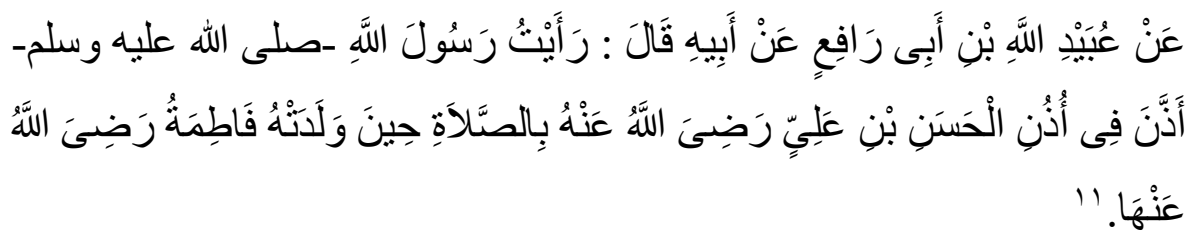

8 'Abd al-Rahman Muhammad 'Abd al-Muhsin al-Anshari, Ma'alim Ushul alTarbiyyah al-Islamiyyah min Khalal Washaya Luqman li Ibnih, Madinah alMunawwarah, Majallah al-Jami'ah al-Islamiyyah, 1418 H., h. 438.

${ }^{9}$ Lihat Muhammad Nawawi, Syarh Sullam al-Munajah, Semarang, Karya Toha Putra, tt., h. 4-5. Bandigkan pula dengan Syarh Safinah al-Najah, Syarh Sullam alTaufiq dan lain-lain masing-masing halaman awal. Hampir semua kitab-kitab kecil yang bermuatan fiqh yang pernah dibaca oleh penulis, membahas ketauhidan terlebih dahulu sebelum membahas tentang muatan intinya (fiqh).

${ }^{10}$ Nawawi al-Banteni, Syarh Maraqi al- 'Ubudiyyah, Surabaya, al-HIdayah, tt., h. 9. Bandingkan dengan: al-Husain bin 'Ali al-Baihaqi, al-Sunan al-Kubra, Beirut, Dar al-Fikr, tt., Juz 3, h. 346.

${ }^{11}$ Ahmad bin al-Husain bin 'Ali al-Baihaqi, al-Sunan al-Kubra, (Haidir Abad: Majlis Dairah al-Ma'arif al-Nizhamiyyah, 1344 H.), cet. ke-1, Juz. 2, h. 197. 
"Dari 'Ubaidillah bin Abi Rafi' dari Ayahnya, dia berkata: Saya melihat Rasulullah saw. mengadzani di telinga (kanannya) al-Husain bin 'Ali Ra. saat di lahirkan oleh Sayyidah Fatimah, dengan adzan (seperti adzannya) shalat."

Dalam adzan, tiga kalimat (kalam) pertama dilantunkan adalah bacaan:

a. الله أكبر (Allah Maha Besar)

b. أنشهي أن لآله إلا الله (Saya bersaksi bahwasanya tidak ada tuhan selain Allah)

c. أثنهد أن محمدا رسول الله له (Saya bersaksi bahwasanya nabi Muhammad itu utusan Allah)

Tiga kalimat (kalam) di atas merupakan seruan bertauhid kepada Allah dan mengakui Muhammad sebagai utusan-Nya. Ini sebagai indikasi, anak yang belum kenal apa-apa harus dimantapkan ajaran tauhidnya. Ini juga menunjukkan bahwa desain kurikulum pendidikan dasar haruslah diprioritaskan ajaran tauhid. Yang utama adalah tauhid merasuk dalam diri peserta didik, teknik dapat beragam, bisa dengan cara integrasi dengan mata pelajaran lain atau menggunakan metode tertentu.

Selain menganjurkan adzan di telinga kanan anak yang baru lahir, Rasulullah saw. juga menganjurkan agar telinga anak tersebut dibisiki surat al-Ikhlas yang isinya juga kalimat-kalimat tauhid, sebagaimana dikutip alShan'ani dalam tulisannya:

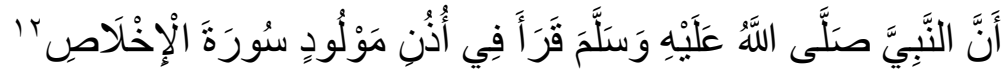

"Sesungguhnya Nabi saw. membacakan surat al-Ikhlas di telinga anak yang baru dilahirkan."

Setelah keimanan anak didik kepada Allah tertancap kuat di dalam hatinya, yang perlu mendapat perhatian dalam pendidikan Islam adalah pendidikan akhlak yang dilakukan Luman yaitu akhlak, baik akhlak kepada orang tua, akhlak kepada Allah melalui perilaku ihsan (muraqabah), atau pun

${ }^{12}$ Al-Shan'ani, Subul al-Salam, Juz ke-6, h. 335. 
akhlak dengan sesama. Perintah shalat oleh Lukman kepada anaknya berada di urutan agak belakangan. Hal ini senada dengan peristiwa sejarah perintah shalat yang baru ada setelah peristiwa Isra' Mi'raj yang kejadiannya beberapa tahun setelah kenabian. ${ }^{13}$ Begitu pula perintah berzakat baru ada dua tahun setelah peristiwa hijrah Nabi ke Madinah sebagaimana perintah berpuasa. Sedangkan perintah beribadah haji baru di tahun keenam setelah hijrah Nabi. ${ }^{14}$

Dengan pendekatan religious dan historis ini menjadi jelas bahwa pendidikan prioritas adalah tauhid yang disampaikan dengan penuh ramah dan rahmah, sehingga pendidikan akhlak sebagai cerminan dari keramahan proses tauhidisasi juga ikut menyertai pendidikan tauhid. Maka, pendidikan tauhid dan akhlak haruslah berjalan berdampingan dalam pendidikan Islam.

Setelah peserta didik mendapatkan pendidikan tauhid dan akhlak secara integral, mereka harus dibekali dengan mata pelajaran-mata pelajaran lain bidang keagamaan baru ditingkatkan pada mata pelajaran keterampilan sesuai kebutuhan mereka, dengan memerhatikan setting social dan skala prioritas. Berikut desain kurikulum pendidikan yang ditawarkan oleh alGhazali,
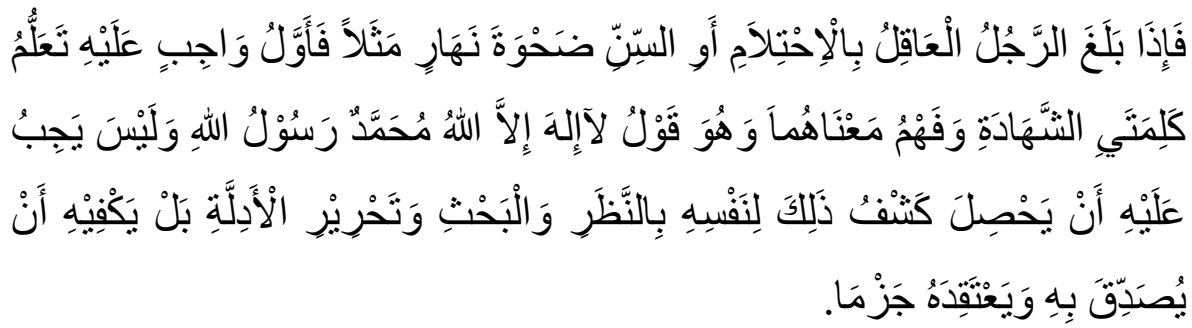

"Manakala seseorang sudah tiba pada usia baligh, apakah ditandai dengan datangnya mimpi basah pada dirinya atau sudah berusia 15 tahun, misalnya,

13 Terdapat perbedaan mengenai tahun kejadian Isra' Mi'raj, tetapi mayoritas mengatakan peristiwa itu terjadi lebih dekat pada masa hijrah daripada masa kenabian. Selengkapnya dapat dibaca pada: Shafiyyurahman al-Mubarakfury, alRahiq al-Makhtum, diterjemah ke dalam Bahasa Indonesia oleh Kathur Suhadi, "Sirah Nabawiyah", Jakarta Timur, Pustaka al-Kautsar, cet. 23, 2007, h. 191.

${ }^{14}$ Keterangan ini diperoleh dari kitab I'anah al-Thalibin pada bab Shalat, Puasa, Zakat, dan Haji. Silakan baca: Abu Bakr Syatha al-Dimyathi, Hasyiyah I'anah alThalibin, Dar al-Fikr, cet. 1, h. 1997. 
hal itu terjadi pada pagi hari, maka pertama kali yang wajib dilakukan oleh orang itu adalah belajar membaca dua kalimat syahadat dan memahami maknanya, yaitu ucapan لا إله إلا الله محد رسول الله ; dan pada kondisi seperti ini, orang itu tidak diwajibkan mengetahui seluk beluk dua kalimat syahadat dengan cara menalar, merenungkan, dan meneliti dalil-dalil yang mendasari dua kalimat syahadat. Di saat itu, yang wajib bagi orang tersebut adalah membenarkan dua kalimat syahadat dan meyakininya saja."

Selanjutnya, al-Ghazali menambahkan, setelah hal di atas diketahui, peserta didik wajib mendapatkan pengetahuan tentang ibadah seperti shalat, puasa, zakat, haji, dan lain-lain, sesuai kebutuhannya, artinya peserta didik yang belum punya harta sampai satu nishab belum butuh belajar zakat dan seterusnya.

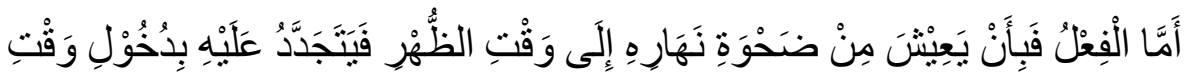

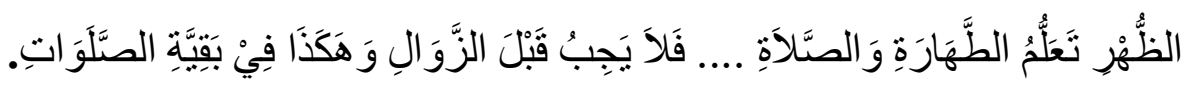

"(setelah mengucapkan dua kalimat syahadat dan meyakininya), misalnya orang tadi masih diberi kesempatan hidup oleh Allah di pagi hari hingga waktu Zhuhur, maka dia baru beralih belajar tata cara bersesuci dan shalat sejak waktu Zhuhur tiba; ..... sedangkan sebelum waktu Zhuhur tiba, dia belum diwajibkan belajar hal itu. Demikian pula halnya shalat-shalat lima waktu yang lain."

Andaikata orang tadi masih panjang umur, maka materi puasa menjadi wajib dipelajari,

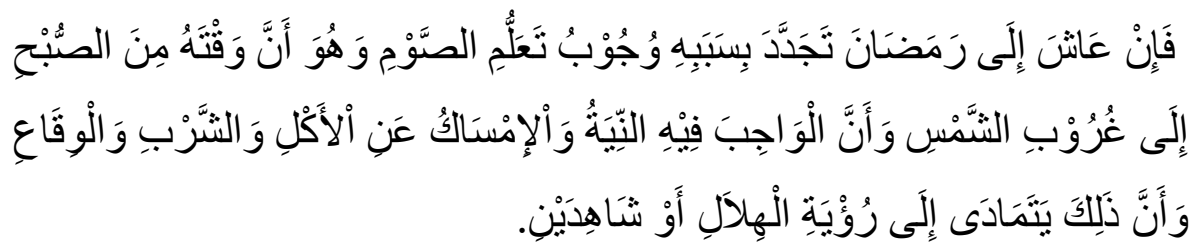

"Kemudian, bilamana orang di atas masih hidup sampai bulan Ramadlan, maka dia memiliki kewajiban baru yaitu belajar hal puasa yang meliputi waktu berpuasa sejak Shubuh sampai terbit matahari, wajib berniat puasa, wajib tidak makan, tidak minum, dan menjauhi hubungan intim. Hal itu semua ditaati sampai terbukti adanya hilal (bulan tanggal 1 Syawal), baik terlihat langsung atau kabar dua orang yang bersaksi akan adanya hilal." 
Yang perlu diperhatikan juga menurut al-Ghazali adalah materi zakat harta,

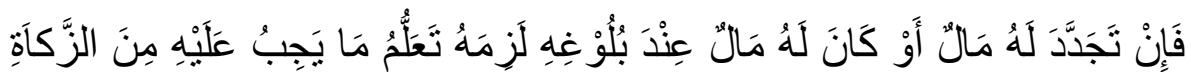

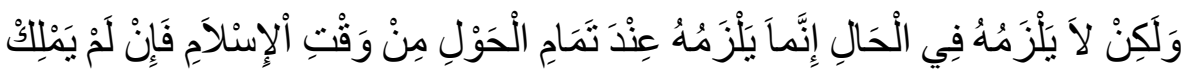

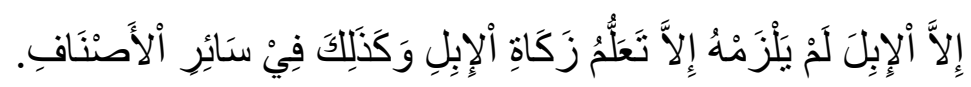

"Jika ternyata orang tersebut punya harta saat baligh awal, atau dia baru memiliki harta yang mencapai ukuran satu nishab, maka orang tersebut berkewajiban mempelajari kewajiban-kewajiban zakat. Kewajiban itu tidak bersifat segera, namun setelah sampai satu tahun terhitung sejak dia memeluk agama Islam. Andaikata yang dia miliki hanya unta, maka dia hanya wajib belajar ketentuan zakat unta, tidak yang lain, dan begitu seterusnya."

Kewajiban selanjutnya adalah materi haji, sebagaimana dikatakan,

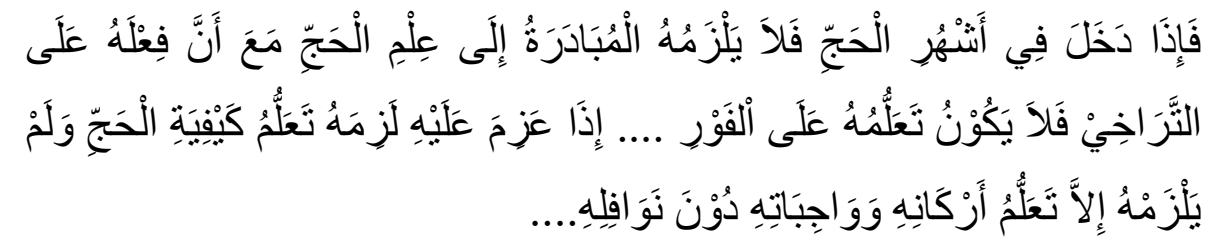

“Jika orang itu memasuki bulan haji, maka tidak perlu terburu-buru belajar urusan haji, sementara kewajiban haji bersifat tidak segera.... Ketika orang tadi sudah bertekad bulat untuk menunaikan ibadah haji, maka ia baru wajib belajar tata cara haji yang pokok-pokok dan yang wajib-wajib saja, dia tidak wajib mempelajari sunnah-sunnahnya."

Orang di atas tidak wajib belajar sunnah-sunnah haji tidak berarti tidak boleh mempelajarinya. Maksudnya adalah hal yang wajib dipelajari adalah pokok-pokok dan wajib-wajib haji saja, sedangkan hal mempelajari sunnah-sunnahnya hukumnya adalah sunnah. Begitu pula di luar kewajibankewajiban yang telah disebutkan di penggalan-penggalan statmen al-Ghazali 
di atas, hal di luar kewajiban di atas yang sifatnya sunnah menjadi sunnah juga hukumnya. ${ }^{15}$

Setelah al-Ghazali menuturkan desain kurikulum yang bersifat wajib personal (fardlu 'ain), selanjutnya menurut beliau penting didistribusikan pelajaran-pelajaran yang bersifat wajib komunal (fardlu kifayah), yaitu suatu kewajiban yang dituntut pada satu komunitas agar ada satu orang atau lebih yang melaksanakannya karena yang menjadi tuntutan pada kewajiban komunal ini adalah terealisirnya kewajiban itu tanpa memandang secara khusus siapa pelaksananya. ${ }^{16}$

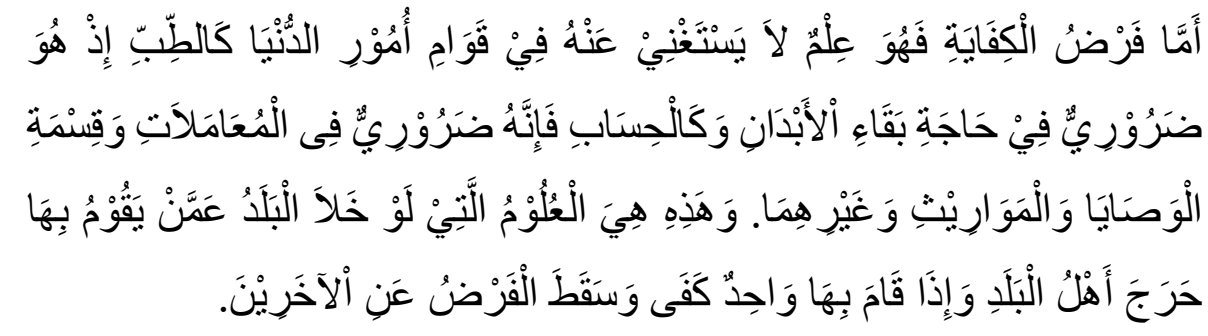

"Ilmu yang bersifat wajib komunal adalah suatu ilmu yang dibutuhkan dalam rangka menjaga tegaknya sendi-sendi kehidupan dunia, misalnya ilmu pengobatan yang sangat dibutuhkan untuk menjaga kesehatan tubuh, ilmu matematika yang sangat dibutuhkan dalam urusan transaksi, pembagian wasiat dan warisan serta selain keduanya. Andaikata ilmu-ilmu ini tidak dimiliki oleh seorang pun di suatu daerah, niscaya mereka akan mengalami kesulitan dan kesengsaraan. Sebaliknya, bila ada satu orang saja yang memiliki ilmu-ilmu tersebut, niscaya cukup bagi daerah itu dan masyarakat yang lain di aerah tersebut bebas dari tuntutan kewajiban mempelajari ilmuilmu tersebut."

\section{Pembahasan tentang Desain Kurikulum Pendidikan Islam Pendekatan Historis-Religius}

Dari pendekatan religious di atas, dapat dipahami bahwa kurikulum pendidikan Islam hendaknya mendahulukan pelajaran tauhid dan akhlak secara integral, lalu pelajaran ibadah ritual seperti shalat, puasa, dan haji, serta

${ }^{15}$ Silakan baca: Abu Hamid Muhammad bin Muhammad al-Ghazali, Ihya' 'Ulum alDin, Beirut, Dar al-Ma'rifah, Juz 1, h. 14.

${ }^{16}$ Zakariya bin Muhammad al-Anshari, Ghayah al-Wushul fi Syarh Lubb al-Ushul, Mesir, Dar al-Kutub al-'Arabiyah al-Kubra, h. 28. 
ibadah sosial seperti zakat, dan terakhir baru memasukkan pelajaran-pelajaran keterampilan seperti ilmu kesehatan, ilmu hitung, dan sebagainya. Penulis memahami kerangka atau desain kurikulum yang ditawarkan al-Ghazali di atas sebagai penjabaran dari pendidikan Lukman terhadap anaknya yang didukung oleh ayat lain dan hadits-hadits tentang pendidikan, karena struktur atau desain tersebut mirip dengan firman Allah yang menceritakan tentang pendidikan Lukman terhadap anaknya.

Selain kemiripan itu, desain kurikulum yang dibuat al-Ghazali juga memiliki kemiripan dengan pola pendidikan Rasulullah yang tergambar melalui historis perjalanan beliau di dalam mendidik umatnya sejak periode Makkah hingga Madinah, di mana awal-awal beliau diutus Allah adalah mengajari umatnya tentang keesaan Allah melalui perilakunya yang terpuji, dan materi pendidikan Rasulullah tentang ibadah baru diberikan kepada umatnya setelah mereka dirasa cukup kuat dalam memegang keyakinan.

Kesan dari pernyataan ini adalah tauhid dan akhlak cukup diajarkan di awal-awal peserta didik mengenyam pendidikan, selanjutnya setelah ketauhidan dan akhlak baik itu tertanam kuat dalam diri mereka maka tidak diperlukan pelajaran tauhid dan akhlak, dan dalam kondisi seperti ini mereka tinggal mengikuti pelajaran-pelajaran berikutnya. Kesan tersebut menjadi terbantahkan dengan firman Allah dalam surat al-Syams ayat $7-8$,

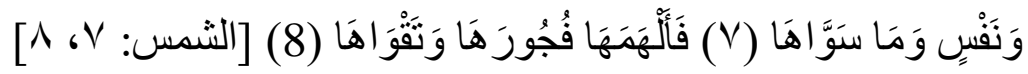
"dan jiwa serta penyempurnaannya (ciptaannya). Maka Allah mengilhamkan kepada jiwa itu (jalan) kefasikan dan ketakwaannya."

Menurut ayat di atas, setiap individu itu berpotensi untuk berbuat baik dan buruk, meningkat dan menurun, mempertahankan keimanan dan terjerumus pada kemunafikan, bahkan kekafiran, dan seterusnya. Dalam salah satu atsar dinyatakan bahwa iman seseorang itu bisa bertambah dan berkurang, ${ }^{17}$ karena iman itu ucapan dan perbuatan, manakala mulut

${ }^{17}$ Ahmad bin Muhammad al-Tsa'labi, al-Kasyf wa al-Bayan 'an Tafsir al-Qur'an, Beirut-Lubnan, Dar Ihya' al-Turats al-'Arabi, cet. 1, 2002, Juz 5, h. 113. 
seseorang berdzikir dan memuji Allah atau tubuh melakkukan ketaatan kepada Allah, niscaya iman orang tersebut akan bertambah, dan sebaliknya. ${ }^{18}$

Untuk mempertahankan ketauhidan dan akhlak mulia yang telah ditanamkan sejak dini pada diri peserta didik kita, maka tidak cukup pendidikan tauhid dan akhlak hanya diajarkan di awal-awal pendidikan mereka lalu ditinggalkan saat anak mempelajari mata pelajaran lain. Oleh karena itu, aroma tauhid harus merambah seluruh ruang mata pelajaran yang lain seperti Biologi, Fisika, Matematika, Bahasa Inggris, Bahasa Indonesia, Sosiologi, dan sebagainya. Allah Subhanahu Wata'ala berfirman,

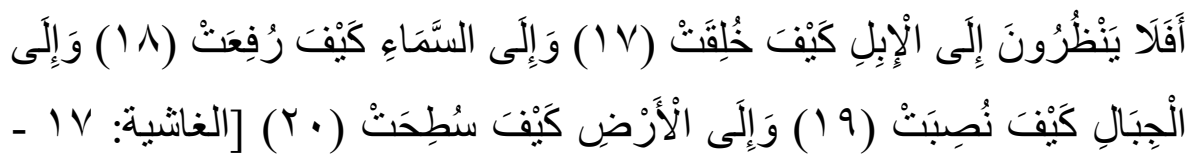

"Maka Apakah mereka tidak memperhatikan unta bagaimana Dia diciptakan, dan langit, bagaimana ia ditinggikan? dan gunung-gunung bagaimana ia ditegakkan? dan bumi bagaimana ia dihamparkan?"

Sebagaimana disinggung di awal-awal, bahwa dorongan Allah untuk merenungkan dan mempelajari unta, langit, gunung, bumi, angin, perahu, dan lautan, pada ayat-ayat di atas tidak semata-mata dorongan melihat dengan mata kepala, melainkan dorongan untuk melihat dengan pikiran mendalam (nazhar) dan mata hati hingga menemukan ilmu pengetahuan, ${ }^{19}$ seperti biologi dari proses memikirkan unta, ilmu astronomi dengan merenungkan pencitaan langit, angin, dan ilmu-ilmu lain. Perenungan dan penghayatan terhadap ilmu-ilmu tersebut pada akhirnya akan sampai pada satu simpulan

${ }^{18}$ Abu Bakr Ahmad bin Muhammad al-Khallal, al-Sunnah, Riyadl, Dar al-Rayah, cet. 1, 1989, Juz 3, h. 591.

${ }^{19}$ Abbas Mahjub, al-Tarbiyyah Fi 'Ushuri ma Qabla al-Islam wa Ba'dahu, Jami'ah Ummu al-Qura, 1980, h. 113. Berikut ini, ungkapan asli dari Abbas Mahjub, فكانت هذه الآيات ومثنيلاتها في القرآن بواعث على إعمال العقل و النظر في الكون و التأمل فيه، مما

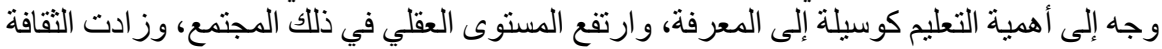
و والمعرفة من القرآن. 
bahwa di balik semua itu adalah Allah Yang Maha Kuasa. ${ }^{20}$ Inilah yang dimaksud dengan tambahnya keimanan dari penghayatan ilmu pengetahuan.

Dalam ilmu Bahasa dan Sosiologi, misalnya, perlu menghadirkan ayat Alqur'an surat al-Rum ayat 22,

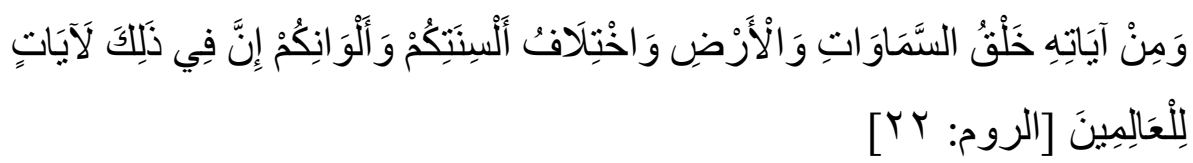

"dan di antara tanda-tanda kekuasaan-Nya ialah penciptaaan langit dan bumi dan berlain-lainan bahasamu dan warna kulitmu. Sesungguhnya pada yang demikan itu benar-benar terdapat tanda-tanda (kebesaran-Nya) bagi orang-orang yang mengetahui (berilmu)."

Perbedaan Bahasa yang disebutkan Allah di dalam ayat itu sangat banyak. Sedangkan Bahasa yang diajarkan di sekolah dan madrasah antara lain adalah Bahasa Arab, Bahasa Inggris, Bahasa Prancis, dan Bahasa-bahasa lain. Saat mengajarkan Bahasa-bahasa tersebut harus disematkan muatanmuatan tauhid hingga para peserta didik mampu menghayati pelajaran Bahasa dan menyadari kehadiran Allah dalam dirinya.

Begitu pula perbedaan warna kulit yang disebutkan juga pada ayat di atas harus mampu mengantarkan peserta didik pada simpulan bahwa di balik ciptaan kulit yang beraneka ragam ini terdapat Dzat Yang Maha Kuasa, karena terkadang dari satu rahim pun terlahir anak yang berlainan warna kulit, dan bahkan pada satu anak sekalipun terkadang ada bagian kulit yang berbeda warna. Pembahasan tentang warna kulit ini bila dipandang dari segi kesukuan merupakan pelajaran Sosiologi yang erat kaitannya dengan ras dan suku bangsa.

${ }^{20}$ Abbas Mahjub, al-Tarbiyyah Fi 'Ushuri ma Qabla al-Islam wa Ba'dahu, Jami'ah Ummu al-Qura, 1980, h. 112. 


\section{E. Penutup}

Penulis dapat menyimpulkan bahwa pembelajaran tauhid dan akhlak harus dilaksanakan secara integral dan simultan dengan pemahaman bahwa pelajaran tauhid harus ditanamkan kepada peserta didik melalui cara-cara yang ramah penuh rahmah sehingga peserta didik menjadi senang menerimanya. Penjabaran ramah penuh rahmah ini disesuaikan dengan metode dan teknik pembelajaran menyenangkan karena tidak ada dalil yang mengharuskan penggunaan metode atau teknik tertentu.

Selain itu, pembelajaran tauhid dan akhlak harus diprioritaskan dengan arti peserta didik harus dikenalkan dengan ketauhidan terlebih dahulu sebelum materi ibadah dan keterampilan dan juga muatan tauhid harus mewarnai materimateri pelajaran lain dalam setiap Kompetensi Dasar atau Indikator Pencapaiannya, setidaknya pada pada mata pelajaran Pendidikan Agama Islam dan Budi Pekerti (PAI-BP).

Dua makna prioritas ketauhidan ini harus dilakukan semua dalam rangka untuk mempertahankan nilai-nilai tauhid dan akhlak yang tertanam sejak dini, bahkan sejak prenatal ketika masih dalam kandungan di mana calon bayi sudah mengakui Allah sebagai Tuhannya.

\section{DAFTAR RUJUKAN}

'Abd al-Rahman Muhammad 'Abd al-Muhsin al-Anshari, Ma'alim Ushul alTarbiyyah al-Islamiyyah min Khalal Washaya Luqman li Ibnih, Madinah alMunawwarah, Majallah al-Jami'ah al-Islamiyyah, $1418 \mathrm{H}$.

Abbas Mahjub, al-Tarbiyyah Fi 'Ushuri ma Qabla al-Islam wa Ba'dahu, Jami'ah Ummu al-Qura, 1980.

Abu 'Abdillah Muhammad bin Ahmad al-Qurthubi, al-Jami' li Ahkam al-Qur'an, Dar al-Kutub al-Mishriyyah, Kairo, cet. 2, 1964, Juz 20.

Abu Bakr Ahmad bin Muhammad al-Khallal, al-Sunnah, Riyadl, Dar al-Rayah, cet. 1, 1989, Juz 3.

Abu Bakr Syatha al-Dimyathi, Hasyiyah I'anah al-Thalibin, Dar al-Fikr, cet. 1.

Abu Hamid Muhammad bin Muhammad al-Ghazali, Ihya' 'Ulum al-Din, Beirut, Dar al-Ma'rifah, Juz 1. 
Abu Manshur Muhammad bin Muhammad al-Maturidi, Tafsir al-Maturidi, Dar alKutub al-'Ilmiyyah, Beirut Lubnan, cet. 1, 2005, Juz 8.

Abu Muhammad Abdu al-Haqq bin 'Athiyyah, al-Muharrar al-Wajiz fi Tafsir alKitab al-'Aziz, Dar al-Kutub al-'Ilmiyyah, Beirut, cet. 1, 1422 H., Juz 4.

Ahmad bin al-Husain bin 'Ali al-Baihaqi, al-Sunan al-Kubra, Haidir Abad, Majlis Dairah al-Ma'arif al-Nizhamiyyah, 1344 H., cet. ke-1, Juz. 2.

Ahmad bin Muhammad al-Tsa'labi, al-Kasyf wa al-Bayan 'an Tafsir al-Qur'an, Beirut-Lubnan, Dar Ihya' al-Turats al-'Arabi, cet. 1, 2002, Juz 5, h. 113.

al-Husain bin 'Ali al-Baihaqi, al-Sunan al-Kubra, Beirut, Dar al-Fikr, tt., Juz 3.

Al-Shan'ani, Subul al-Salam, Juz ke-6.

Muhammad Nawawi, Syarh Maraqi al- 'Ubudiyyah, Surabaya, al-HIdayah, tt.

Muhammad Nawawi, Syarh Sullam al-Munajah, Semarang, Karya Toha Putra, tt.

Samsul Nizar, Sejarah dan Pergolakan Pemikiran Pendidikan Islam, Quantum Teaching, Ciputat, cet. I, 2005.

Shafiyyurahman al-Mubarakfury, al-Rahiq al-Makhtum, diterjemah ke dalam Bahasa Indonesia oleh Kathur Suhadi, "Sirah Nabawiyah”, Jakarta Timur, Pustaka alKautsar, cet. 23, 2007.

Zakariya bin Muhammad al-Anshari, Ghayah al-Wushul fi Syarh Lubb al-Ushul, Mesir, Dar al-Kutub al-'Arabiyah al-Kubra. 